УДК 351.86

DOI https://doi.org/10.32836/2310-9653-2020-3.20

\author{
О. О. Тихоненко, магістр з державної безпеки \\ Інституту Управління державної охорони України \\ Київського національного університету \\ імені Тараса Шевченка
}

\title{
МОДЕЛЮВАННЯ ЗАБЕЗПЕЧЕННЯ ДЕРЖАВНОЇ БЕЗПЕКИ З ВИКОРИСТАННЯМ ПРОФАЙЛІНГУ ПОРУШНИКА
}

У статті розглянуто створення моделі державного управління у сфері гарантування державної безпеки з використанням специфічної технології, яка за допомогою комплексу методів окремих самостійних наук вивчає людину на предмет ї̈ безпеки чи загрози, дозволяє ідентифікувати потенційно небезпечних осіб, спрогнозувати їхню деструктивну поведінку. Визначено сутність гарантування державної безпеки, відповідно до чинного законодавства. Здійснено порівняльний аналіз визначення сутності та відмінності таких понять, як «загроза», «виклик» та «ризик» у контексті державного управління безпеки держави. Зокрема, особлива увага приділяється внутрішнім і зовнішнім потенційним та реальним загрозам і ризикам, щзо містять за джерелом свого виникнення та реалізаиії антропогенну складову частину - порушника. У даному контексті порушник розглядається з позииії моделювання його профілю, щуо містить сукупність кількісних, психологічних, якісних та інших характеристик, що будуть мати виражені специфічні ознаки-ідентифікатори. Такі ознаки-ідентифікатори дозволять виділити порушника серед інших суб'єктів об'єкта гарантування безпеки - держави, до створення ним певних несприятливих умов, явищ, чинників, відповідно відреагувати, нейтралізувати реалізацію загрози державній безпеці та/або мінімізувати можливі втрати, збиток.

3 позиії державного управління розглянуто та визначено можливість удосконалення механізму гарантування державної безпеки шляхом створення універсальної моделі державного управління у сфері гарантування держсавної безпеки $з$ використанням моделі та профілю реального і потенційного, внутрішнього та зовнішнього порушника, з відповідними заходами реагування щодо їх виявлення та запобігання реалізаиії деструктивних дій щчодо об'єкта гарантування безпеки.

Ключові слова: профайлінг, державна безпека, ризик, загроза, порушник, модель порушника, модель безпеки.

\section{O. O. Tykhonenko. Modeling of state security with the use of violator profiling}

The article discusses the creation of a model of public administration in the field of state security using a specific technology, which, using a set of methods of some independent sciences, studies a person for his safety or threat, allows you to identify potentially dangerous people and predict them destructive behavior. The essence of ensuring state security in accordance with the current legislation has been determined. A comparative analysis of the definition of the essence and differences of concepts such as "threat", "challenge" and "risk" in the context of public safety management, in particular, special attention is paid to internal and external potential and real threats and risks that are contained in the source in their origin and implementation of the anthropogenic component-intruder. In this context, the offender is considered from the point of view of modeling his profile, which contains a set of quantitative, psychological, qualitative and other characteristics, which, accordingly, will have certain identifiers. Such identifying signs will make it possible to single out the violator among other subjects of the security object - the state, before they create certain unfavorable conditions, phenomena, factors and respond accordingly, neutralizing the threat to the security of the state and / or minimizing possible losses and damage.

From the point of view of public administration, the possibility of improving the mechanism of state security by creating a universal model of public administration in the field of state security using the model and profile of real and potential internal and external violators, with appropriate measures to identify and prevent destructive actions in relation to the security object.

Key words: profiling, state security, risk, danger, offender, violator model, state security model.

Постановка проблеми. Сучасні несприятливі умови, у яких нині перебуває країна, а саме: підвищення рівня злочинності, терористичних актів із захопленням заручників, втрата територій, військовий конфлікт на сході країни тощо, вимагають реформування сектора гарантування безпеки держави та захисту національних інтересів. Зважаючи на вищевказані негативні тенденції, для здійснення ефективного управління у сфері державної безпеки необхідно використовувати сучасні наукові розробки, аналізувати як позитивний, так і негативний вітчизняний та закордонний досвід, брати до уваги ймовірнісний характер різних негативних процесів, явищ і чинників. Наявна модель державного управління сфери гарантування державної безпеки потребує вдосконалення, насамперед із позиції можливості запобігання виникненню та реалізації загроз, викликів та ризиків щодо безпеки країни.

Аналіз останніх досліджень і публікацій. Дослідження проблемних аспектів, пов'язаних із функціонуванням системи державного управління загалом та у сфері державної безпеки зокрема на сучасному етапі розвитку держави залишаються актуальними в колі таких вітчизняних науковців, як: Л.А. Жукова, Н.Г. Клименко, Г.П. Ситника, О.С. Бикова, О.О. Труша, А.Б. Качинський, А.В. Терент’єва й інші.

Мета статті - висвітлення можливості вдосконалення державного управління у сфері державної безпеки шляхом створення моделі гарантування державної безпеки з використанням профайлінгу.

(C) О. О. Тихоненко, 2020 
Виклад основного матеріалу. У світовій науці поширені декілька визначень поняття «держава». Наприклад, Цицерон визначав державу як певну організацію правопорядку, М.С. Грушевський у своїх працях визначав державу як сукупність людей, території та суверенної влади, Платон - як певний процес із підкорення невеликою войовничою організованою групою людей значно більшого за чисельністю, але менш організованого населення, Карл Маркс уявляв державу як машину для придушення одного класу іншим. Проте з позиції державного управління ми визначимо державу як територію із чітко визначеними кордонами, на якій відбувається певна кількість різноманітних процесів та явищ, розташовані об'єкти та системи як живої, так і неживої природи, матеріальні, технічні, соціальні, релігійні, культурні й інші цінності. У сучасних умовах українська держава представлена як суверенна, політико-територіальна організація влади певної частини населення, у соціально-неоднорідному суспільстві, що має спеціальні апарати управління та примусу, що за допомогою права виголошує свої веління та робить їх загальнообов' язковими для всього населення країни, здійснює управління загальносуспільними процесами, водночас вищим нормативно-правовим актом є Конституція України [1].

Згідно з даним актом, людина, її життя і здоров’я, честь та гідність, недоторканість та безпека визнаються найвищою соціальною цінністю, а одним із головних обов'язків держави визнається гарантування нею (державою - О. Т.) безпеки кожного громадянина, людини. Отже, грунтуючись на сукупному, узагальненому трактуванні поняття «держава», ми зафіксуємо той факт, що населення є невід’ємною складовою частиною держави, тому їі безпеку деякою мірою можна ототожнити з безпекою кожного громадянина, людини в рамках державної матриці. У результаті розгляду інших нормативно-правових актів, що так чи інакше стосуються держави, ми виділили таке.

Згідно із Законом України «Про національну безпеку України» [2], безпека держави є складовою частиною національної безпеки, а згідно зі ст. 3 цього Закону, «об'єктами національної безпеки є людина і громадянин та їх конституційні права і свободи, суспільство, його духовні, морально-етичні, культурні, історичні, інтелектуальні та матеріальні цінності, інформаційне і навколишнє природне середовище, природні ресурси та держава, ii територіальна цілісність, недоторканість, суверенітет і конституційний лад». Зокрема, за вищезгаданим нами Законом України процес гарантування безпеки держави не має чітко визначеної системи, що складалась би 3 певних регламентованих процесів, дій тощо, однак у ньому зафіксований той факт, за яким головне призначення системи гарантування державної безпеки - відвернення потенційних та реальних загроз.

Важливою особливістю загрози, у рамках державної безпеки, є антропогенна складова частина - дії чи бездіяльність людини. Таку людину, що створює несприятливі умови для сталого функціонування та розвитку держави, ми визначаємо порушником. 3 огляду на вищезазначені факти та міжнародний досвід застосування профайлінгу у сфері безпеки, у разі адаптації технології профайлінгу під завдання з гарантування безпеки держави ми можемо створити модель виявлення антропогенних загроз - реальних чи потенційних порушників.

У наявних умовах багатьма спеціалістами вважається, що найбільш актуальні загрози натепер такі: політичні - зростання недовіри населення до органів влади та місцевого самоврядування через корумпованість та низьку ефективність; економічні - «тінізація» національної економіки; терористичні - диверсійно-розвідувальна та підривна діяльність іноземних спеціальних служб на території України з метою посягання на державний суверенітет та цілісність; соціально-кримінальні - загальна тенденція тривожності й аномії в суспільстві внаслідок погіршення життя та матеріального добробуту громадян, за яких у пересічного громадянина зникають чіткі межі встановлених законом норм і правил у поведінці, руйнуються суспільні цінності, як наслідок підвищення рівня злочинності; інші.

Якщо проаналізувати виникнення та розвиток вищевказаних загроз, важко не помітити, що реалізація неможлива без певної дії чи бездіяльності людини, що в даному разі створює собою такі чинники, явища та тенденції, що унеможливлюють, ускладнюють (потенційно можуть це зробити - $O$. T.) реалізацію національних інтересів та збереження національних цінностей.

Виходячи $з$ вищезазначеного, держава як об’єкт, щодо якого вживаються заходи з гарантування його безпеки, - об'єкт забезпечення безпеки (далі - ОЗБ), за своїм змістом є багатокомпонентним та включає в себе такі специфічні складові елементи, як: територія, населення, що визначається за територіальною приналежністю, суверенітет, система права, апарат публічної влади, податкова та фінансова системи, апарат примусу, збройні сили (військо), державна мова, державна символіка. Отже, у даному разі поняття ОЗБ буде охоплювати не тільки об'єкт, а й суб'єкта, ми розуміємо ці терміни так: суб'єкт - це громадянин, людина, особистість, як носій певних якостей, прав, обов'язків та свобод; об'єкт - будь-які об’єкти флори та фауни; складові частини навколишнього середовища, майно (зокрема, державні та приватні споруди, будинки, предмети тощо); ресурси, інформація, що мають матеріальну, історичну, культурну й іншу цінність для суб’єкта гарантування безпеки.

Наступним розглянемо поняття «безпека» з позиції безпеки як процесу та безпеки як стану. Сучасна наука має специфічне уявлення про безпеку, розглядає іï як свого роду багатогранний феномен у межах окремих самостійних наук різних сфер - юридичної, воєнної, політичної, соціальної й інших. У контексті держави безпека передбачає синхронізацію та взаємодію великої кількості інститутів різних сфер життєдіяльності людини, суспільства, держави, що створює синергічний системний ефект сталого суспільного розвитку. 
У процесі розгляду поняття «безпека» нами відзначається той факт, що у спеціальній літературі частіше за все трапляється таке трактування даного поняття: «стан захищеності життєво важливих інтересів особистості, суспільства, держави від внутрішніх та зовнішніх загроз», «здатність предмета, явища чи процесу зберігатися в разі руйнівного впливу». Якщо звернутися знову до Закону України «Про національну безпеку України», ми спостерігаємо, що в даному разі безпека визначається як певний стан, а саме «захищеність державного суверенітету, територіальної цілісності і демократичного конституційного ладу та інших життєво важливих національних інтересів від реальних і потенційних загроз невоєнного характеру». Якщо розглянути дане поняття у філософському аспекті, то безпеку можна уявити як стан відсутності будь-якої небезпеки, тобто дії щодо об’ єкта, що заперечує, заважає, перешкоджає його існуванню, певну відсутність першочергових необхідних життєвих умов для існування такого об'єкта. Отже, з вищезазначеного виходить, що безпека як певний стан є суспільною потребою та важливим принципом сталого розвитку людини, суспільства, держави, а по своїй суті являє собою крайнє значення небезпеки, коли вона фактично відсутня. Виходячи з вищезазначеного, гарантування безпеки, тобто безпеку як процес, можна трактувати як певні специфічні дії суб'єкта ОЗБ, що спрямовані на захист від небезпек.

У спеціалізованій навчально-методичній літературі, що вивчає процес гарантування безпеки та відповідних реакцій щодо несприятливих умов, процесів, чинників, останній здійснюється певними складовими частинами (інститутами) системи безпеки, у формі алгоритму таких дій, як: моніторинг небезпек; виявлення небезпек на начальному етапі до розвитку небезпечного етапу, коли ОЗБ можуть бути завдані втрати, збиток; запобігання небезпекам, що дозволяє уповільнити процес їх реалізації та зменшити рівень впливу на ОЗД; ліквідація або нейтралізація виявленої небезпеки, тобто припинення процесу завдання втрат, що дозволяє звести до розумного мінімуму наслідки реалізації небезпеки, тобто мінімізувати можливі втрати; документування, аналіз й узагальнення отриманого досвіду в цілях удосконалення використаних засобів та методів, недопущення виникнення і реалізації схожих негативних явищ, процесів тощо.

Чинне законодавство специфічними несприятливими умовами - небезпеками - визначає наявні та потенційно можливі чинники, що не сприяють, заважають, перешкоджають реалізації життєво важливих інтересів держави, а поняття «небезпека» є основним у визначенні поняття «загроза». Водночас у спеціальній літературі, у контексті понять «загроза» та «небезпека», трапляються й такі поняття, як «ризик» та «виклик», що вживаються в характеристиці деяких чинників, які так чи інакше впливають на безпеку загалом. Саме тому в нас під час створення моделі гарантування безпеки держави з використанням методу профайлінгу постає необхідність розглянути дані поняття окремо і більш детально.

У процесі вивчення поняття небезпеки ми спостерігаємо, що кожен спеціаліст, дослідник, обирає, визначає чи трактує його таким чином, що на його особисто-суб'єктивний погляд має найбільше значення в тому контексті, що ним вивчається, висвітлюється. Щоб наочно продемонструвати цей факт, наведемо декілька прикладів. А.Б. Качинський трактує поняття «загроза» як явище із прогнозованими, але не контрольованими, не бажаними подіями, а в разі їх виникнення на певній території, у певний проміжок часу, вони можуть спричинити матеріальні й інші збитки, завдати шкоди здоров’ю та життю людей тощо [3]. Водночас, якщо звернутися до тлумачного словника Д.М. Ушакова, ми спостерігаємо, що в даному джерелі загроза визначається неоднорідно: у першому разі - як обіцянка спричинити кому-небудь шкоду; у другому - як небезпека, можливість виникнення чого-небудь неприємного [4].

Виходячи із завдань і того факту, що натепер немає єдиної трактовки даного терміна, у процесі розроблення моделі гарантування державної безпеки з використанням технології профайлінгу перед нами постає необхідність детально розглянути дане поняття, особливо там, де воно вживається в контексті специфічних державних процесів. Також зазначимо, що в результаті проведеного аналізу спеціалізованих вітчизняних та міжнародних джерел ми виділили деякі умови, несприятливі процеси, події, за яких вони можуть бути внутрішніми чи зовнішніми та різними за характером - природними, економічними, політичними, технічними, соціальними тощо.

Зазначимо, що в процесі вивчення інформаційних джерел ми спостерігали, що велика кількість фахівців у контексті небезпек уживають такі терміни, як «виклик», «ризик» та «загроза», часто - як синоніми. Так, поняття «виклик» здебільшого розуміють як сукупність специфічних обставин, не обов'язково загрозливого характеру, але таких, що вимагають реагувати на них із метою запобігання (та/або зниження) можливим збиткам. Зокрема, ризик розуміють як можливість такого явища, результату діяльності (бездіяльності) людини, що призведе до наслідків, які впливають (можуть вплинути) на виникнення (існування) ситуації, у результаті якої формуються передумови несприятливої ситуації для всіх життєво необхідних процесів існування та сталого розвитку ОЗБ. У результаті такого формулювання поняття «ризик», «виклик» та «загроза»є схожими, тобто майже не відрізняються одне від одного. Натомість нами було проаналізовано певну кількість інформаційних джерел [5; 6; 7; 8] та визначено, що, хоча натепер немає єдиного, універсального визначення понять «ризик», «виклик» та «загроза», проте в багатьох джерелах простежується той факт, що вони часто не є тотожними поняттями з багатьох причин, наприклад, з погляду сценарного аналізу. Щоби продемонструвати таку їхню відмінність, нами було проведено порівняльний аналіз даних понять, що наведено в таблиці 1. 
У результаті проведення такого порівняльного аналізу ми встановили, що загроза в даному порівняльному контексті виявляється таким специфічним негативним явищем, чинником, подією, що може бути важко прогнозованою, оціненою, тому що дане явище (чинник, подія) ще не відбулося в реальному часі, тобто щодо нього немає достатньої, конкретної інформації для ефективного виявлення, запобігання, мінімізації наслідків, збитків, втрат тощо. Така специфічна особливість загроз унеможливлює розроблення ефективних профілактичних чи оперативних заходів. Отже, загроза - це такий несприятливий чинник, що важко прогнозується, піддається аналізу, натомість ризик, навпаки, піддається кількісному аналізу, прогнозується як його реальність здійснення, настання так і можливі наслідки, збитки тощо. Резюмуючи вищезазначене, ми зробили висновки, згідно з якими можна розглядати ризики, виклики та загрози як різні ступені небезпеки, згідно із чим ризик виступає найбільш низьким ступенем небезпеки, виклик - як середній, а загроза - як найвищий.

Таблиця 1

Порівняння понять «загроза», «виклик» та «ризик»

\begin{tabular}{|c|c|c|}
\hline Ризик & Загроза & Виклик \\
\hline $\begin{array}{c}\text { Характеристика події, ситуації, } \\
\text { що має певну невизначеність } \\
\text { результату, за обов'язкової наявності } \\
\text { несприятливих наслідків. }\end{array}$ & $\begin{array}{c}\text { Сукупність умов і чинників, } \\
\text { які можуть стати причиною } \\
\text { порушення цілісності, доступності, } \\
\text { конфіденційності. }\end{array}$ & $\begin{array}{c}\text { Є виявлення (прогнозовані) стану } \\
\text { планети і людського соціуму, довільний } \\
\text { розвиток яких із неминучістю призведе } \\
\text { до погіршення загального стану людства і } \\
\text { загрожує його існуванню як біологічного } \\
\text { виду й організованого соціуму. }\end{array}$ \\
\hline $\begin{array}{c}\text { Невизначена подія, умова, яка, } \\
\text { у разі виникнення, має позитивний чи } \\
\text { негативний вплив, може призвести до } \\
\text { матеріальних втрат суб'єкта. }\end{array}$ & $\begin{array}{c}\text { Висловлений в будь-якій формі намір } \\
\text { завдати фізичної, матеріальної чи } \\
\text { іншої шкоди суспільним } \\
\text { чи особистим інтересам. }\end{array}$ & $\begin{array}{l}\text { Деяка важка проблема, для вирішення якої } \\
\text { потрібні великі зусилля, сміливість тощо. }\end{array}$ \\
\hline Кількісна оцінка небезпек. & $\begin{array}{c}\text { Залякування, обіцянки завдати } \\
\text { кому-небудь шкоди. }\end{array}$ & Запрошення до певної дії. \\
\hline $\begin{array}{c}\text { Імовірність виходу небезпечного } \\
\text { чинника з-під контролю з можливими } \\
\text { наслідками, що можна виразити } \\
\text { кількісно. }\end{array}$ & $\begin{array}{c}\text { Реальна небезпека, можливість } \\
\text { завдання шкоди, можливість } \\
\text { настання описаного поєднання } \\
\text { ситуації і стану взаємодії об’єктів, } \\
\text { що робить загрозу реальною. }\end{array}$ & $\begin{array}{c}\text { Запрошення прийняти бій, вступити } \\
\text { в боротьбу, змагання тощо. }\end{array}$ \\
\hline $\begin{array}{c}\text { Імовірність можливої } \\
\text { небажаної втрати чого-небудь за } \\
\text { небажаного збігу обставин. }\end{array}$ & $\begin{array}{c}\text { Об’єктивний, тобто зовнішній } \\
\text { мало або неконтрольований } \\
\text { агентом тренд, подія, що спричиняє } \\
\text { небезпеку втрат, збитку, шкоди } \\
\text { або сприймається як такий. }\end{array}$ & $\begin{array}{c}\text { Запрошення, вимагання прибути, } \\
\text { приїхати кудись. }\end{array}$ \\
\hline $\begin{array}{c}\text { Можливість виникнення несприятливої } \\
\text { ситуації або невдалого результату } \\
\text { виробничо-господарської } \\
\text { або будь-якої іншої діяльності. }\end{array}$ & Це можлива небезпека. & $\begin{array}{c}\text { Вимагання виходу на сцену виконавця, } \\
\text { що виражається певними діями - } \\
\text { вигуками, оплесками тощо. }\end{array}$ \\
\hline $\begin{array}{c}\text { Це така негативна тенденція розвитку } \\
\text { соціуму, що була виявлена, } \\
\text { яка знижує, ускладнює можливість } \\
\text { позитивного розвитку нації. }\end{array}$ & $\begin{array}{c}\text { Це ймовірність руйнівного впливу, } \\
\text { тобто події. }\end{array}$ & $\begin{array}{c}\text { Дія, що спричиняє } \\
\text { появлення чогось, когось. }\end{array}$ \\
\hline
\end{tabular}

У процесі розроблення моделі, з погляду забезпечення ефективного процесу державного управління та гарантування державної безпеки, ввівши профайлінг, ми зосередили увагу на важливих умовах й ефективних процесах засвоєння та переводу загрози у виклик, а виклик у ризик із подальшими заходами з його нейтралізації чи мінімізації наслідків, збитків. Зворотний процес переводу ризику у виклик, а виклику у загрозу, тобто процесу накопичення, кумуляції ризиків, буде являти собою ознаки слабкої за ефективністю моделі гарантування безпеки. Тому аналіз будь-якої проблеми державної безпеки доцільно розглядати з позиції аналізу ризиків, викликів і загроз та можливостей переводу загроз у ризики, а не навпаки. Застосуванням профайлінгу в даній моделі ми унеможливлюємо такий процес, бо профілювання порушника дозволяє виявити антропогенні ризики на початковому етапі їх виникнення, а відповідне реагування дозволить не допустити переводу їх у загрози.

3 метою спрощення процесів визначення небезпеки ОЗБ під час створення моделі ми залишаємо крайні варіанти небезпек - ризик та загрозу, загальноприйняте поняття «виклик» ми не беремо до уваги, проте введемо таке поняття, як «уразливість ОЗБ». Така перемінна, на наш погляд, буде раціональнішою, бо дозволить деякою 
мірою порівнювати стан безпечності ОЗБ у співвідношенні з мінімальними чи максимальними рівнями прояву небезпеки.

Також відзначимо той факт, що у процесі розгляду феномену небезпеки ми визначили, що небезпеки мають як негативне, так і позитивне значення, бо дозволяють у разі правильної оцінки негативних наслідків сформувати відповідне адекватне ставлення до того чи іншого явища, процесу, предмета, саме тому необхідно враховувати отриманий досвід, аналізувати його, вносити в модель корективи. Отже, з аналізу й узагальнення як позитивного, так і негативного досвіду в рамках даного напряму простежується позитивна тенденція щодо формування загального процесу гарантування безпеки ОЗБ, з визначенням його вразливостей та створення ефективної моделі гарантування безпеки держави.

Для правильної оцінки та прогнозування наслідків фахівцями з управління небезпеками прийнято розділяти їх за окремими критеріями. Загрози існують у кожній сфері життєдіяльності, вони перебувають зовні та всередині окремої особистості, суспільства, держави, тому в даній моделі ми виділяємо два види антропогенного ризику внутрішній та зовнішній.

Згідно з Конституцією України [1], обов'язком держави є гарантування безпеки кожного громадянина, людини, але водночас, якщо розглядати антропогенну складову частину небезпеки, іноді і людина, громадянин також може являти собою небезпеку для самого себе, іншої людини, суспільства, держави. Отже, логічно, що в такому разі сили, на які, згідно із Законом України «Про національну безпеку України» [2], покладено завдання з гарантування безпеки держави, можуть мати ризики, пов'язані з антропогенним чинником загрози, тобто реальних чи потенційних внутрішніх порушників. Такий порушник буде характеризуватися тим, що має легальний доступ до об'єкта гарантування безпеки чи його складових елементів, має певний, легалізований (законом, нормативно-правовими актами тощо) вплив у межах своїх посадових, функціональних та інших повноважень, можливостей тощо.

Неможливо не зазначити, що така специфічна ситуація, у якій перебуває країна, створює негативні умови щодо тривожності й аномії в суспільстві з негативною тенденцією його криміналізації, що супроводжуються діями, які становлять загрозу державній безпеці. Такі тенденції також невід'ємно пов'язані 3 антропогенним чинником загрози, тобто ми можемо виділити такий негативний антропогенний елемент ризику, як реальний чи потенційний зовнішній порушник. Такий порушник буде характеризуватися тим, що не має легального доступу до ОЗБ чи його елементів, не має певних, легалізованих (законом, нормативно-правовими актами тощо) впливів у межах своїх посадових, функціональних та інших повноважень чи можливостей.

Відповідно до об'єкта гарантування безпеки, перед розробленням заходів із його убезпечення проводиться визначення основної мети, цілей та завдань щодо створення вищезазначених заходів, визначення характеристик об'єкта, наявних (реальних) та потенційних вразливостей і загроз, 3 подальшим створенням моделі порушника.

Мета, завдання та цілі повинні визначатися Президентом України, який відповідно ст. 102 Конституції України [1] $є$ «Главою держави і виступає від іiі імені, є гарантом державного суверенітету, територіальної цілісності України, є гарантом додержання Конституції України, прав і свобод людини i громадянина». У рамках вищезазначеної особливості необхідно провести створення окремого органу, що буде підпорядковуватись та звітувати безпосередньо Президенту України, мати врегульований законом імунітет, права й обов'язки.

Даний орган повинен мати структуру, відповідно до визначених Президентом України цілей, мети і завдань,

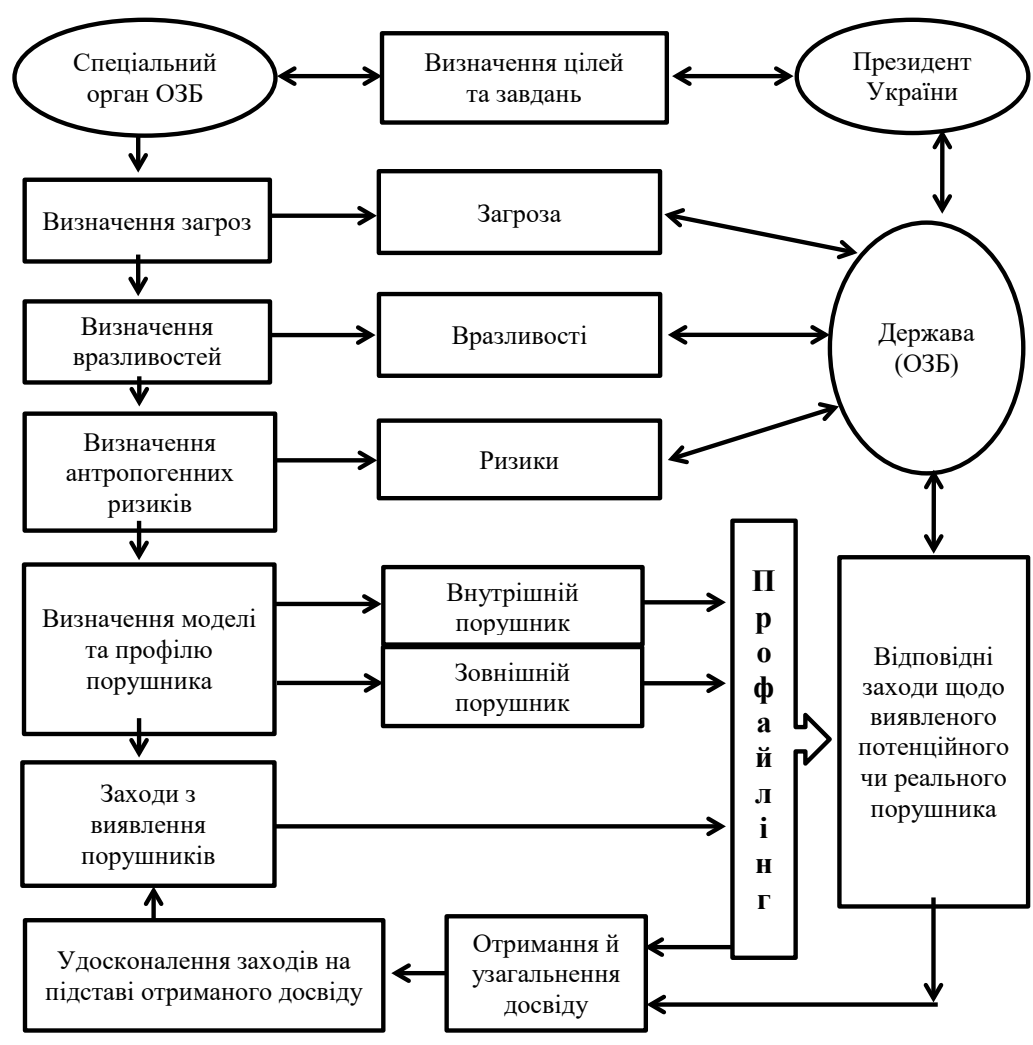

Рис. 1. Модель державного управління гарантування державної безпеки з використанням профайлінгу 
та складатися з відповідної структури, що містить спеціалістів які здійснюють профайлінг (профайлери). Також відповідним органам необхідно розробити та впровадити нормативно-правовий акт «Про проведення профайлінгу осіб, у рамках гарантування державної безпеки та захисту національних інтересів».

Якщо порушником є людина - живий організм, якому властиві певні поведінкові, емоційні стани та специфічні алгоритми поведінки, ми, спираючись на таку особливість, наступним кроком вводимо розробку моделі порушників, відповідно до визначеної реальної чи потенційної загрози, яка буде містити профіль особи порушника.

Зокрема, під таким профілем ми розуміємо суб'єкта (групу), що за результатами своїх дій, умисних чи неумисних, та / або бездіяльності, забезпечує реалізацію загроз безпеці ОЗБ. Отже, відповідно до специфіки об'єкта та / або його окремо взятого складового елемента, наявна та чи інша модель порушника, що включає в себе профіль порушника із притаманними йому специфічними поведінковими ознаками, особливостями рис характеру, емоційними станами, спеціальних знань чи вмінь, використанням приладів, обладнання, озброєння тощо.

3 урахуванням вищевказаного ми маємо таку модель державного управління гарантування державної безпеки з використанням профайлінгу.

Висновки з дослідження і перспективи подальших розвідок у цьому напрямі. Практичне значення застосування профайлінгу порушника в моделі державного управління у сфері державної безпеки полягає в опорі на систематизований вітчизняний та закордонний досвід гарантування безпеки, комплексний підхід до різних ситуацій, знаходження причинно-наслідкового зв'язку між різного роду подіями, з подальшим логічним аналізом фактів. Моніторинг та профілювання суб'єктів ОЗБ, відповідно до їх потенційної загрози щодо об'єкта гарантування безпеки (держава) дозволить раціонально підійти до класичної або інноваційної системи заходів державного управління гарантуванням безпеки, розраховувати сили та засоби тощо. Відповідно до вищевказаного, система моніторингу і відповідних реакцій із виявленню порушників із використанням профайлінгу повинна постійно вдосконалюватися, грунтуючись на аналізі отриманого досвіду, що дозволить даній системі постійно самовдосконалюватись.

\section{Список використаних джерел:}

1. Конституція України, ред. від 1 січня 2020 р. № 254к/96-BP. URL: https://zakon.rada.gov.ua/laws/ show $/ 254 \% \mathrm{D} 0 \% \mathrm{BA} / 96-\% \mathrm{D} 0 \% \mathrm{~B} 2 \% \mathrm{D} 1 \% 80$ (дата звернення: 08.08.2020).

2. Про національну безпеку України : Закон України, ред. від 15 березня 2020 р. № 2469-VIII. URL: https://zakon.rada.gov.ua/laws/show/2469-19\#Text (дата звернення: 08.08.2020).

3. Качинський Б.А. Індикатори національної безпеки: визначення та застосування їхніх граничних значень : монографія. Київ : НІСД, 2013. 104 с.

4. Толковый словарь русского языка / под ред. Д.Н. Ушакова. URL: http://www.dict.t-mm.ru/ushakov/u/ugryo. html (дата звернення: 08.08.2020).

5. Даль В.И. Толковый словарь русского языка : для школьников : содержит более 10000 слов. Минск : Харвест, 2010. 511 с.

6. Ожегов С.И. Толковый словарь русского языка. Москва, 2012. 1375 с.

7. Кауфман И.М. Терминологические словари. Москва, 1961. 419 с.

8. Академічний тлумачний словник української мови (1970-1980) URL: http://sum.in.ua/ (дата звернення: 22.03.2020).

\section{References:}

1. Ukraine. Verkhovna Rada of Ukraine. "The Constitution of Ukraine" [Konstytutsiia Ukrainy]. dated January 01, 2020 № 254K/96-BP URL: https://zakon.rada.gov.ua/laws/show/254\%D0\%BA/96-\%D0\%B2\%D1\%80 (related to 08.08.2020) [Ukraine]

2. Ukraine. Verkhovna Rada of Ukraine. Law of Ukraine "On National Security of Ukraine". [Zakon Ukrainy "Pro natsionalnu bezpeku Ukrainy”]. dated 15 March 15, 2020 № 2469-VIII. URL: https://zakon.rada.gov.ua/laws/ show/2469-19\#Text (related to 08.08.2020) [Ukraine]

3. Kaczynski B.A. (2013), Indykatory natsionalnoi bezpeky: vyznachennia ta zastosuvannia yikh hranychnykh znachen [Indicators of national security: definition and application of their limit values], Monograph, Press NISD, Kiev. $104 \mathrm{p}$ [Ukraine]

4. Explanatory dictionary of the Russian language D.N. Ushakov, Tolkovyi slovar russkogo yazyka D.N. Ushakova, URL: http://www.dict.t-mm.ru/ushakov/u/ugryo.html (related to 08.08.2020) [Ukraine]

5. Dahl. V.I. (2010), Tolkovyi slovar V.I. Dalia dlia shkolnikov: soderjit bolee 10000 slov [Explanatory dictionary of V.I. Dahl for schoolchildren: contains more than 10,000 words], Press Harvest, Minsk. 511 p. [Ukraine]

6. Ozhegov S.I. (2012), Tolkovyi slovar russkogo yazyka [Explanatory dictionary of the Russian language], Press Moscow. 1375 p. [Ukraine]

7. Kaufman I.M. (1961), Termynolohycheskye slovary [Terminological dictionaries]. Press Moskva. 419 p. [Ukraine]

8. Slovnyk ukrainskoi movy Akademichnyi tlumachnyi slovnyk (1970-1980) [Dictionary of the Ukrainian language Academic explanatory dictionary (1970-1980)] URL: http://sum.in.ua/ (related to 08.08.2020) [Ukraine]. 